\title{
SCREENING OF MUNGBEAN VARIETIES FOR RESISTANCE AGAINST MAJOR INSECT PESTS IN SOUTHERN REGION OF BANGLADESH
}

\author{
K.N. Islam ${ }^{1 *}$, M.M. Uddin ${ }^{2}$, M.M.H. Khan ${ }^{3}$, M.M. Islam ${ }^{4}$ and M.A. Monim ${ }^{5}$ \\ ${ }^{1}$ OFRD, Bangladesh Agricultural Research Institute, Patuakhali, Bangladesh \\ ${ }^{2}$ Department of Entomology, Bangladesh Agricultural University, Mymensingh, Bangladesh \\ ${ }^{3}$ Department of Entomology, Patuakhali Science and Technology University, Bangladesh \\ ${ }^{4}$ Soil Conservation and Water Management Centre, Soil Resource Development Institute, \\ Bandarban, Bangladesh \\ ${ }^{5}$ Regional Agricultural Research Station, Bangladesh Agricultural Research Institute, \\ Barishal, Bangladesh
}

\begin{abstract}
Fifteen varieties of mungbean were evaluated for resistance against major insect pests i.e., leaf folder (Cnaphalocrocis medinalis), flea beetle (Phyllotreta nigripes), thrips (Megalurothrips distalis), gram pod borer (Helicoverpa armigera) and legume pod borer (Maruca vitrata). Screening was done on the basis of incidence of insect pests from first incidence upto harvest. Statistically significant variation on recorded data was observed at different days after sowing. The lowest leaf folder population was recorded on variety BARI Mung-4 (1.08 larvae per plot) while the highest (2.05) on variety BARI Mung-6. The flea beetle population was the lowest on variety BARI Mung-4 (1.67 flea beetles per plot) while the highest (3.04) was recorded on variety BARI Mung-6. The lowest population of thrips was observed on variety BARI Mung-4 (1.43 thrips per 10 opened flowers) and the highest population (2.67) was observed on variety BINA Moog-7. The lowest gram pod borer population was observed on variety BARI Mung-4 (1.03 caterpillars per plot) while the highest gram pod borer population was observed on variety BARI Mung-6 (2.24). The lowest population of legume pod borer was observed on variety BINA Moog-4 (1.18 larvae per plot) while the highest population (2.75) was recorded on variety BARI Mung-6. Among the tested varieties, BARI Mung-4 was proven comparatively the least pest infested and highest resistant variety. On the contrary, BARI Mung6 showed least resistance. Rest of the varieties expressed moderately resistance to major insect pests. The results showed that none of the tested varieties was completely resistant to major insect pests.
\end{abstract}

*Corresponding Author: kbd_nazrul@yahoo.com 
Keywords: flea beetle, gram pod borer, leaf folder, legume pod borer, thrips, resistance

\section{INTRODUCTION}

Mungbean (Vigna radiata) belonged to the family Fabaceae and sub-family Papilionaceae, is an important legume crop grown widely in Bangladesh. It is a popular crop in Bangladesh not only as a food crop but also as a fodder crop. The agro-ecological conditions of this country suit its cultivation. It is grown in three seasons in a year in Bangladesh and more than $70 \%$ mungbean area is concentrated in the three southern districts viz. Patuakhali, Barisal and Noakhali within AEZ 13 and 18, and Patuakhali alone occupies about 30\% area (Mondol et al., 2013). It is an important source of protein and several essential micronutrients (Bakr et al., 2004). Besides providing protein in the diet, mungbean can also fix atmospheric nitrogen through symbiotic relationship with soil bacteria and improve the soil fertility (Yadav et al., 1994).

Mungbean is one of the most promising pulse crops in Bangladesh and there are many constraints for its low yield. Among many constraints, insect pest is considered to be the important one. The relative abundance of different species of insect pest of mungbean is not identical in all seasons. The severity of damage is related with the abundance of different insect pests and environmental conditions. Several insect pests have been reported to infest mungbean and damage the seedlings, leaves, stems, flowers, buds, pods causing considerable losses (Sehgal and Ujagir, 1988; Karim and Rahman, 1991). Depending on the growing season, management practices and crop variety the abundance and infestation level of insect pests of mungbean existed separately.

Among major insects leaf folder (Cnaphalocrocis medinalis), flea beetle (Phyllotreta nigripes), thrips (Megalurothrips distalis), gram pod borer (Helicoverpa armigera) and legume pod borer (Maruca vitrata) are the most susceptible and devastating to the climatic condition of Bangladesh. In mungbean, the larvae of leaf folder feed on the lower surface of leaves when they are young and as they grow, they feed on the edges of leaves and roll inwards up to the mid rib into a trumpet shape fastened by means of silken thread and feed on leaf tissues. The larvae remain inside the roll and feed outside the marginal portion of the leaves. Severe infestation results in complete defoliation of the plant or even plant may die. Heavy infestation of flea beetle in mungbean causes leaves to dry up and the plant growth is rendered with few pods. It feeds on the cotyledons, making the severe innumerable round holes on leaves of young plants and ultimately dried the older damaged leaves. Thrips has become the most serious pest of mungbean. It is associated mostly with the damage of tender buds and flower of mungbean (Lal, 1985). Severe infestation of thrips resulted flower shedding causing significant yield loss (Chhabra and Kooner, 1985; Lal, 1985). In the field, gram pod borer and legume pod borer are considered to be a major insect pest 
in Bangladesh. This insect is highly devastating to pods. The larvae bore into the young pods, remain there and feed on the seeds inside. Pod borers often cause serious problem resulting severe loss of the crop (Bakr, 1998). Apart from mungbean, this pest is also reported to be a serious pest of pigeon pea in India (Patnaik et al., 1986). However, the major constraint for poor yields is the wide array of insect pests, which attack the plants from seedling to maturity. Keeping these factors in views, the present study was conducted with fifteen varieties of mungbean to screen the varieties with resistance against major insect pests.

\section{MATERIALS AND METHODS}

\section{Cultivation of mungbean}

The study was conducted during late Rabi season in 2016 at farmers' field of southern region under the agroecological zone (AEZ) 13 (Ganges Tidal Flood Plain). The experimental site was at Patuakhali sadar upazila under Patuakhali district in Bangladesh which is located in between $22^{\circ} 14^{\prime}$ and $22^{\circ} 29^{\prime}$ North latitudes and in between $90^{\circ} 12^{\prime}$ and 90 $28^{\prime}$ East longitudes (BANGLAPEDIA: National Encyclopedia of Bangladesh, 2015). This area is adjacent to the Bay of Bengal and lies at 0.9 to 2.1 metre above mean sea level (Iftekhar and Islam, 2004). Particularly in the areas of southern region, mungbean crop could be grown in late Robi (winter period) from mid January to mid February. The winter period is short due to close proximity to the Bay of Bengal. The seeds of the mungbean varieties namely viz., BARI Mung-1, BARI Mung-2, BARI Mung-3, BARI Mung-4, BARI Mung-5, BARI Mung-6, BINA Moog-4, BINA Moog-5, BINA Moog-6, BINA Moog-7, BINA Moog-8, BU Mug-1, BU Mug-2, BU Mug-4 and Patuakhali local Mung for screening against major insect pestswere sown on 19 January with making rows maintaining spacing $(30 \mathrm{~cm} \times 10 \mathrm{~cm})$. The experiment was laid out in a Randomized Complete Block Design (RCBD) with 3 replications. Each replication represented a block which was divided into 15 -unit plots. The individual plot $(4.0 \mathrm{~m} \times 2.5 \mathrm{~m})$ was made ready as per treatment design. 15 varieties were randomly allotted to the plot. The fertilizers were applied as per Krishi Projukti Hatboi (BARI, 2011). The sources of $\mathrm{N}, \mathrm{P}_{2} \mathrm{O}_{5}$ and $\mathrm{K}_{2} \mathrm{O}$ were Urea, triple super phosphate (TSP) and Muriate of Potash (MoP) were applied @ 50-85-35 kg/ha, respectively. Whole amount of urea, the entire amounts of TSP and MoP were applied in the field uniformly during the final land preparation. The fertilizers were then mixed properly with the soil by spading and individual unit experimental plots were leveled. All intercultural operations were done when necessary to ensure normal growth and development of crops. None of the insecticides was applied to protect the crop from the infestation ofinsect pests.

\section{Data collection}

Data on the number of leaf folder, flea beetle, thrips, gram pod borer and legume pod borer were recorded at different days after sowing (DAS). Population of insect pests was recorded at an interval of 7 days commencing from first incidence during 
different growth stages of the crop. All plants from each unit plot were observed individually and the number of leaf folder, flea beetle, gram pod borer and legume pod borer were recorded at early in the morning (6.30-9.00 AM). The population was counted by visual eye method and with the help of magnifying glass from each unit plot. The population data for leaf folder and flea beetle were collected five times at different $(18,25,32,39,46)$ days after sowing (DAS). Similarly, the data on the population of gram pod borer and legume pod borer were collected three times at different $(51,58,65)$ days after sowing (DAS). In case of the population of thrips, this population were recorded three times at different $(32,39,46)$ days after sowing (DAS). Thrips population was assessed from 10 opened flowers which were randomly collected from five plants of the plot avoiding border rows and central four rows. Then the collected flowers were opened on the white paper board and counted the thrips.

\section{Statistical analysis}

Data were analyzed statistically through ANOVA using Web Agri Stat Package. The insect population data were subjected to square root $(\sqrt{x}+0.5)$ transformation before statistical analysis. Treatment means were compared by critical difference (CD) values at $5 \%$ level of significance.

\section{RESULTS AND DISCUSSION}

\section{Population of leaf folder on different varieties at different days after sowing}

From the Table 1, population of leaf folder (Cnaphalocrocis medinalis) on the tested mungbean varieties varied from 0.71 to $1.46,0.88$ to $1.86,1.34$ to $2.91,0.88$ to 2.11 and 0.88 to 1.94 at $18,25,32,39$ and 46 days after sowing (DAS), respectively and the results differed significantly. Similarly, mean number of leaf folder showed variation from 1.08 to 2.05 among the tested varieties. The number of leaf folder per plot was the lowest (1.08) on BARI Mung-4 followed by BINA Moog-4 (1.10) which was statistically identical to that of BINA Moog-5 (1.10) whereas the highest (2.05) was on BARI Mung-6 followed by BINA Moog-7 (1.89), BARI Mung-5 (1.61) and BARI Mung-3 (1.41). Leaf folder was of little importance but at present it has assumed alarming proportion on mungbean. Our present findings are in accordance with the results reported by Islam et al., (2021) who have screened 15 mungbean varieties under natural infestation of leaf folder and none was found to be resistant against leaf folder. 
Table 1. Performance of different mungbean varieties against leaf folder per plot at days after sowing (DAS)

\begin{tabular}{l|r|r|r|r|r|r}
\hline \multirow{2}{*}{ Varieties } & \multicolumn{7}{|c|}{ Number of leaf folder per plot at } & \multirow{2}{*}{} \\
\cline { 2 - 6 } & 18 DAS & \multicolumn{1}{c}{ 25 DAS } & 32 DAS & 39 DAS & 46 DAS & \multicolumn{1}{c}{ Mean } \\
\hline BARI Mung-1 & $0.88 \mathrm{c}$ & $1.29 \mathrm{bcd}$ & $1.65 \mathrm{~cd}$ & $1.27 \mathrm{bcd}$ & $1.17 \mathrm{bc}$ & $1.25 \mathrm{def}$ \\
BARI Mung-2 & $0.71 \mathrm{c}$ & $1.17 \mathrm{bcd}$ & $2.06 \mathrm{bcd}$ & $1.65 \mathrm{abcd}$ & $1.05 \mathrm{bc}$ & $1.33 \mathrm{def}$ \\
BARI Mung-3 & $0.71 \mathrm{c}$ & $1.27 \mathrm{bcd}$ & $2.20 \mathrm{abc}$ & $1.81 \mathrm{abc}$ & $1.05 \mathrm{bc}$ & $1.41 \mathrm{~cd}$ \\
BARI Mung-4 & $0.88 \mathrm{c}$ & $1.05 \mathrm{~cd}$ & $1.72 \mathrm{bcd}$ & $0.88 \mathrm{~d}$ & $1.05 \mathrm{bc}$ & $1.08 \mathrm{f}$ \\
BARI Mung-5 & $1.00 \mathrm{bc}$ & $1.56 \mathrm{abc}$ & $2.00 \mathrm{bcd}$ & $2.04 \mathrm{ab}$ & $1.46 \mathrm{ab}$ & $1.61 \mathrm{bc}$ \\
BARI Mung-6 & $1.46 \mathrm{a}$ & $1.86 \mathrm{a}$ & $2.91 \mathrm{a}$ & $2.08 \mathrm{ab}$ & $1.94 \mathrm{a}$ & $2.05 \mathrm{a}$ \\
BINA Moog-4 & $0.71 \mathrm{c}$ & $1.05 \mathrm{~cd}$ & $2.23 \mathrm{abc}$ & $1.17 \mathrm{~cd}$ & $1.00 \mathrm{bc}$ & $1.10 \mathrm{ef}$ \\
BINA Moog-5 & $0.88 \mathrm{c}$ & $0.88 \mathrm{~d}$ & $1.34 \mathrm{~d}$ & $1.35 \mathrm{abcd}$ & $0.88 \mathrm{c}$ & $1.10 \mathrm{ef}$ \\
BINA Moog-6 & $0.71 \mathrm{c}$ & $1.17 \mathrm{bcd}$ & $1.94 \mathrm{bcd}$ & $1.17 \mathrm{~cd}$ & $0.88 \mathrm{c}$ & $1.17 \mathrm{def}$ \\
BINA Moog-7 & $1.34 \mathrm{ab}$ & $1.86 \mathrm{a}$ & $2.90 \mathrm{a}$ & $2.11 \mathrm{a}$ & $1.22 \mathrm{bc}$ & $1.89 \mathrm{ab}$ \\
BINA Moog-8 & $0.88 \mathrm{c}$ & $1.34 \mathrm{abcd}$ & $2.26 \mathrm{abc}$ & $1.29 \mathrm{abcd}$ & $1.05 \mathrm{bc}$ & $1.36 \mathrm{cde}$ \\
BU Mug-1 & $0.71 \mathrm{c}$ & $1.65 \mathrm{ab}$ & $2.39 \mathrm{abc}$ & $0.88 \mathrm{~d}$ & $0.88 \mathrm{c}$ & $1.30 \mathrm{def}$ \\
BU Mug-2 & $1.00 \mathrm{bc}$ & $1.17 \mathrm{bcd}$ & $2.40 \mathrm{abc}$ & $1.34 \mathrm{abcd}$ & $1.05 \mathrm{bc}$ & $1.39 \mathrm{~cd}$ \\
BU Mug-4 & $0.88 \mathrm{c}$ & $1.46 \mathrm{abc}$ & $1.86 \mathrm{bcd}$ & $1.18 \mathrm{~cd}$ & $1.00 \mathrm{bc}$ & $1.28 \mathrm{def}$ \\
Patuakhali local & $1.05 \mathrm{abc}$ & $0.88 \mathrm{~d}$ & $2.48 \mathrm{ab}$ & $1.05 \mathrm{~cd}$ & $1.05 \mathrm{bc}$ & $1.30 \mathrm{def}$ \\
Mung & 29.78 & 25.27 & 22.15 & 35.27 & 29.03 & 12.00 \\
\hline CV (\%) & 0.45 & 0.55 & 0.79 & 0.84 & 0.54 & 0.28 \\
CD (0.05) & & & & &
\end{tabular}

Means having dissimilar letter(s) differ significantly at 0.05 level of probability. CD- Critical Difference

\section{Population of flea beetle on different varieties at different days after sowing}

From the Table 2, population of flea beetle (Phyllotreta nigripes) on the tested mungbean varieties varied from 0.88 to $2.04,1.56$ to $2.67,2.27$ to $3.91,2.10$ to 3.93 and 1.39 to 2.68 at $18,25,32,39$ and 46 days after sowing (DAS), respectively and the results differed significantly. Similarly, mean number of flea beetle showed variations from 1.67 to 3.04 among the tested varieties. Population of flea beetle was the lowest (1.67) on BARI Mung-4 followed by BINA Moog-4 (1.93) and BARI Mung-3 (1.96) whereas the highest (3.04) on BARI Mung-6 which was statistically similar to that of BINA Moog-7 (3.01) followed by BINA Moog-6 (2.29), BARI Mung-1 (2.28). The results of the present investigation were similar to the finding of Islam et al., (2021) who reported that, among the tested varieties none of the variety showed complete resistance against flea beetle. 
Table 2. Performance of different mungbean varieties against flea beetle per plot at days after sowing (DAS)

\begin{tabular}{|c|c|c|c|c|c|c|}
\hline \multirow[b]{2}{*}{ Varieties } & \multicolumn{5}{|c|}{ Number of flea beetle per plot at } & \multirow[b]{2}{*}{ Mean } \\
\hline & 18 DAS & 25 DAS & 32 DAS & 39 DAS & 46 DAS & \\
\hline BARI Mung-1 & $1.56 \mathrm{abc}$ & $2.30 \mathrm{abc}$ & $2.55 \mathrm{bcd}$ & $2.94 \mathrm{cdef}$ & $2.04 \mathrm{abcd}$ & $2.28 \mathrm{bc}$ \\
\hline BARI Mung-2 & $1.52 \mathrm{abc}$ & $1.74 \mathrm{~cd}$ & $2.49 \mathrm{~cd}$ & $3.53 \mathrm{abc}$ & $1.95 \mathrm{bcd}$ & $2.24 \mathrm{bc}$ \\
\hline BARI Mung-3 & $1.05 \mathrm{bc}$ & $1.72 \mathrm{~cd}$ & $2.76 \mathrm{bcd}$ & $2.45 \mathrm{efg}$ & $1.84 \mathrm{bcd}$ & $1.96 \mathrm{bcd}$ \\
\hline BARI Mung-4 & $0.88 \mathrm{c}$ & $1.56 \mathrm{~d}$ & $2.27 \mathrm{~d}$ & $2.26 \mathrm{fg}$ & $1.39 \mathrm{~d}$ & $1.67 \mathrm{~d}$ \\
\hline BARI Mung-5 & $1.17 \mathrm{~b} \mathrm{c}$ & $1.95 \mathrm{bcd}$ & $3.12 \mathrm{abc}$ & $3.58 \mathrm{abc}$ & $1.39 \mathrm{~d}$ & $2.24 \mathrm{bc}$ \\
\hline BARI Mung-6 & $2.04 \mathrm{a}$ & $2.67 \mathrm{a}$ & $3.33 \mathrm{ab}$ & $3.93 \mathrm{a}$ & $2.68 \mathrm{a}$ & $3.04 \mathrm{a}$ \\
\hline BINA Moog-4 & $0.88 \mathrm{c}$ & $1.68 \mathrm{~d}$ & $3.02 \mathrm{bcd}$ & $2.10 \mathrm{~g}$ & $1.96 \mathrm{abcd}$ & $1.93 \mathrm{~cd}$ \\
\hline BINA Moog-5 & $1.27 \mathrm{bc}$ & $1.76 \mathrm{~cd}$ & $3.01 \mathrm{bcd}$ & $2.42 \mathrm{efg}$ & $2.04 \mathrm{abcd}$ & $2.10 \mathrm{bc}$ \\
\hline BINA Moog-6 & $1.68 \mathrm{ab}$ & $1.77 \mathrm{~cd}$ & $2.52 \mathrm{bcd}$ & $3.36 \mathrm{abcd}$ & $2.15 \mathrm{abc}$ & $2.29 \mathrm{~b}$ \\
\hline BINA Moog-7 & $2.02 \mathrm{a}$ & $2.43 \mathrm{ab}$ & $3.91 \mathrm{a}$ & $3.81 \mathrm{ab}$ & $2.53 \mathrm{ab}$ & $3.01 \mathrm{a}$ \\
\hline BINA Moog-8 & $1.05 \mathrm{bc}$ & $1.76 \mathrm{~cd}$ & $2.45 \mathrm{~cd}$ & $3.22 \mathrm{abcd}$ & $1.77 \mathrm{~cd}$ & $2.05 \mathrm{bc}$ \\
\hline BU Mug-1 & $1.17 \mathrm{bc}$ & $1.76 \mathrm{~cd}$ & $2.59 \mathrm{bcd}$ & $2.79 \mathrm{defg}$ & $2.18 a b c$ & $2.10 \mathrm{bc}$ \\
\hline BU Mug-2 & $1.18 \mathrm{bc}$ & $1.86 \mathrm{bcd}$ & $2.27 \mathrm{~d}$ & $3.21 \mathrm{abcd}$ & $2.33 \mathrm{abc}$ & $2.17 \mathrm{bc}$ \\
\hline BU Mug-4 & $1.17 \mathrm{bc}$ & $1.74 \mathrm{~cd}$ & $2.62 \mathrm{bcd}$ & 2.80 defg & $2.26 \mathrm{abc}$ & $2.12 \mathrm{bc}$ \\
\hline $\begin{array}{l}\text { Patuakhali } \\
\text { local Mung }\end{array}$ & $1.27 \mathrm{bc}$ & $1.77 \mathrm{~cd}$ & $2.27 \mathrm{~d}$ & 3.13 bcde & $2.03 \mathrm{abcd}$ & $2.09 \mathrm{bc}$ \\
\hline CV (\%) & 31.92 & 18.69 & 18.04 & 14.29 & 21.06 & 9.79 \\
\hline $\mathrm{CD}(0.05)$ & 0.71 & 0.59 & 0.83 & 0.72 & 0.72 & 0.37 \\
\hline
\end{tabular}

Means having dissimilar letter(s) differ significantly at 0.05 level of probability, CD- Critical Difference

\section{Population of thrips on different varieties at different days after sowing}

From the Table 3, population of thrips (Megalurothrips distalis) on the tested mungbean varieties varied from 1.46 to $2.70,1.77$ to 3.08 and 1.05 to 2.24 at 32,39 and 46 days after sowing (DAS), respectively and the results differed significantly. Similarly, mean number of thrips showed variations from 1.43 to 2.67 among the tested varieties. The highest population of thrips (2.67) was observed on BINA Moog-7 followed by BARI Mung-5 (2.29) and BINA Moog-5 (2.21) which was statistically similar to that of BARI Mung-6 (2.19) and BU Mug-2 (2.16). But the lowest population of thrips (1.43) was found on BARI Mung-4 followed by BARI Mung-1 (1.69) and BARI Mung-2 (1.93) which was significantly similar to that of 
Patuakhali local Mung (1.93). Similar consistent results have also been reported by Nadeem et al. (2014) who has screened ten cultivars of mungbeanviz., MH 3153, MH 5251, MH 5254, MH 5255, MH 34143, MH 34144, MH 34164, MH 34241 and two check varieties i.e., NM 2006 (Check 1), AZRI 2006 (Check 2) for resistance against thrips and none was found complete resistant which was similar to the findings of Khattak et al., (2004).

Table 3. Performance of different mungbean varieties against thrips per 10 opened flowers at days after sowing (DAS)

\begin{tabular}{l|r|r|r|r}
\hline \multirow{2}{*}{ Varieties } & \multicolumn{3}{|c|}{ Number of thrips per plot at } & \multirow{2}{*}{ Mean } \\
\cline { 2 - 4 } & \multicolumn{1}{|c}{$32 \mathrm{DAS}$} & \multicolumn{1}{c}{$39 \mathrm{DAS}$} & \multicolumn{1}{c}{$46 \mathrm{DAS}$} & \\
\hline BARI Mung-1 & $1.74 \mathrm{bc}$ & $1.93 \mathrm{~cd}$ & $1.17 \mathrm{~d}$ & $1.69 \mathrm{~cd}$ \\
BARI Mung-2 & $2.03 \mathrm{~b}$ & $2.32 \mathrm{bcd}$ & $1.47 \mathrm{bcd}$ & $1.93 \mathrm{bc}$ \\
BARI Mung-3 & $2.04 \mathrm{~b}$ & $2.32 \mathrm{bcd}$ & $1.56 \mathrm{abcd}$ & $1.97 \mathrm{bc}$ \\
BARI Mung-4 & $1.46 \mathrm{c}$ & $1.77 \mathrm{~d}$ & $1.05 \mathrm{~d}$ & $1.43 \mathrm{~d}$ \\
BARI Mung-5 & $2.11 \mathrm{~b}$ & $2.66 \mathrm{ab}$ & $2.11 \mathrm{ab}$ & $2.29 \mathrm{ab}$ \\
BARI Mung-6 & $2.08 \mathrm{~b}$ & $2.73 \mathrm{ab}$ & $1.64 \mathrm{abcd}$ & $2.19 \mathrm{~b}$ \\
BINA Moog-4 & $1.86 \mathrm{bc}$ & $1.86 \mathrm{~d}$ & $2.00 \mathrm{abc}$ & $1.19 \mathrm{bc}$ \\
BINA Moog-5 & $2.11 \mathrm{~b}$ & $2.51 \mathrm{abc}$ & $2.03 \mathrm{abc}$ & $2.21 \mathrm{~b}$ \\
BINA Moog-6 & $1.94 \mathrm{bc}$ & $2.69 \mathrm{ab}$ & $1.46 \mathrm{bcd}$ & $2.02 \mathrm{bc}$ \\
BINA Moog-7 & $2.70 \mathrm{a}$ & $3.08 \mathrm{a}$ & $2.24 \mathrm{a}$ & $2.67 \mathrm{a}$ \\
BINA Moog-8 & $1.95 \mathrm{bc}$ & $2.61 \mathrm{ab}$ & $1.44 \mathrm{bcd}$ & $2.00 \mathrm{bc}$ \\
BU Mug-1 & $2.04 \mathrm{~b}$ & $2.67 \mathrm{ab}$ & $1.56 \mathrm{abcd}$ & $2.08 \mathrm{bc}$ \\
BU Mug-2 & $1.86 \mathrm{bc}$ & $2.59 \mathrm{ab}$ & $2.03 \mathrm{abc}$ & $2.16 \mathrm{~b}$ \\
BU Mug-4 & $2.04 \mathrm{~b}$ & $2.40 \mathrm{bcd}$ & $1.56 \mathrm{abcd}$ & $2.00 \mathrm{bc}$ \\
Patuakhali local Mung & $1.86 \mathrm{bc}$ & $2.60 \mathrm{ab}$ & $1.35 \mathrm{~cd}$ & $1.93 \mathrm{bc}$ \\
\hline CV (\%) & 15.83 & 15.71 & 26.27 & 12.14 \\
CD (0.05) & 0.53 & 0.64 & 0.72 & 0.55 \\
\hline
\end{tabular}

Means having dissimilar letter(s) differ significantly at 0.05 level of probability, CD- Critical Difference

\section{Population of gram pod borer on different varieties at different days after sowing}

From the Table 4, population of gram pod borer (Helicoverpa armigera) on the tested mungbean varieties varied from 0.88 to $2.20,1.22$ to 2.48 and 0.88 to 2.04 at 51,58 and 65 days after sowing (DAS), respectively and the results differed significantly. Similarly, mean number of gram pod borer showed variations from 1.03 to 2.24 among the tested varieties. Population trend of gram pod borer was the lowest (1.03) 
on BARI Mung-4 followed by (1.19) BARI Mung-3 which was statistically similar to that of BINA Moog-4 (1.22) whereas the highest population was (2.24) on BARI Mung-6 followed by BINA Moog-7 (1.93) and BINA Moog-5 (1.88). The present study is in agreement with that of Shafique et al., (2009) who observed the varieties for resistance against chickpea pod borer (Helicoverpa armigera) infestation in a field and none of the tested genotypes showed complete resistant against chickpea pod borer.

Table 4. Performance of different mungbean varieties against gram pod borer per plot at days after sowing (DAS)

\begin{tabular}{|c|c|c|c|c|}
\hline \multirow[b]{2}{*}{ Varieties } & \multicolumn{3}{|c|}{ Number of gram pod borer per plot at } & \multirow[b]{2}{*}{ Mean } \\
\hline & $51 \mathrm{DAS}$ & $58 \mathrm{DAS}$ & 65 DAS & \\
\hline BARI Mung-1 & $1.27 \mathrm{bcd}$ & $1.82 \mathrm{bc}$ & 1.44 abcde & $1.45 \mathrm{~cd}$ \\
\hline BARI Mung-2 & $1.00 \mathrm{~cd}$ & $1.44 \mathrm{~cd}$ & 1.27 bcde & $1.24 \mathrm{cde}$ \\
\hline BARI Mung-3 & $1.00 \mathrm{~cd}$ & $1.56 \mathrm{bcd}$ & $1.00 \mathrm{e}$ & $1.19 \mathrm{de}$ \\
\hline BARI Mung-4 & $0.88 \mathrm{~d}$ & $1.34 \mathrm{~cd}$ & $0.88 \mathrm{e}$ & $1.03 \mathrm{e}$ \\
\hline BARI Mung-5 & $1.10 \mathrm{~cd}$ & $1.87 \mathrm{bc}$ & 1.47 abcde & $1.48 \mathrm{~cd}$ \\
\hline BARI Mung-6 & $2.20 \mathrm{a}$ & $2.48 \mathrm{a}$ & $2.04 \mathrm{a}$ & $2.24 \mathrm{a}$ \\
\hline BINA Moog-4 & $1.05 \mathrm{~cd}$ & $1.22 \mathrm{~d}$ & 1.39 abcde & $1.22 \mathrm{de}$ \\
\hline BINA Moog-5 & $2.04 \mathrm{ab}$ & $1.76 \mathrm{bcd}$ & $1.86 \mathrm{abc}$ & $1.88 \mathrm{~b}$ \\
\hline BINA Moog-6 & $1.17 \mathrm{~cd}$ & $1.65 \mathrm{bcd}$ & 1.17 cde & $1.33 \mathrm{cde}$ \\
\hline BINA Moog-7 & $1.74 \mathrm{abc}$ & $2.08 \mathrm{ab}$ & $1.95 \mathrm{ab}$ & $1.93 \mathrm{ab}$ \\
\hline BINA Moog-8 & $1.05 \mathrm{~cd}$ & $1.56 \mathrm{bcd}$ & $1.87 \mathrm{abc}$ & $1.49 \mathrm{~cd}$ \\
\hline BU Mug-1 & $1.29 \mathrm{bcd}$ & $1.65 \mathrm{bcd}$ & $1.10 \mathrm{de}$ & $1.35 \mathrm{cde}$ \\
\hline BU Mug-2 & $1.27 \mathrm{bcd}$ & $1.64 \mathrm{bcd}$ & 1.56 abcde & $1.49 \mathrm{~cd}$ \\
\hline BU Mug-4 & $1.29 \mathrm{bcd}$ & $1.68 \mathrm{bcd}$ & $1.77 \mathrm{abcd}$ & $1.58 \mathrm{bc}$ \\
\hline Patuakhali local Mung & $1.27 \mathrm{bcd}$ & $1.74 \mathrm{bcd}$ & $1.19 \mathrm{cde}$ & $1.50 \mathrm{~cd}$ \\
\hline $\mathrm{CV}(\%)$ & 35.27 & 20.17 & 29.95 & 14.36 \\
\hline $\mathrm{CD}(0.05)$ & 0.77 & 0.57 & 0.74 & 0.35 \\
\hline
\end{tabular}

Means having dissimilar letter(s) differ significantly at 0.05 level of probability. CD- Critical Difference

\section{Population of legume pod borer on different varieties at different days after sowing}

From the Table 5, population of legume pod borer (Maruca vitrata) on the tested mungbean varieties varied from 0.88 to $2.39,1.56$ to 3.75 and 0.71 to 2.11 at 51,58 and 65 days after sowing (DAS), respectively and the results differed significantly. Similarly, mean number of legume pod borer showed variations from 1.18 to 2.75 
among the tested varieties. Population of legume pod borer was the lowest (1.18) on BINA Moog-4 which was statistically similar to that of (1.21) BARI Mung-3 followed by (1.58) BINA Moog-3 whereas, the highest (2.75) was observed on BARI Mung-6 which was statistically similar to that of BINA Moog-7 (2.40) followed by BARI Mung-5 (2.28) and BARI Mung-4 (1.89). The findings of the present study are also supported by the findings of Sandhya Rani et al., (2014) who monitored 110 different genotypes including 10 released varieties as check under field condition against pod borer and no genotype was found as resistant to Maruca vitrata.

Table 5. Performance of different mungbean varieties against legume pod borer per plot at days after sowing (DAS)

\begin{tabular}{|c|c|c|c|c|}
\hline \multirow[b]{2}{*}{ Varieties } & \multicolumn{3}{|c|}{ Number of legume pod borer per plot at } & \multirow[b]{2}{*}{ Mean } \\
\hline & $51 \mathrm{DAS}$ & $58 \mathrm{DAS}$ & 65 DAS & \\
\hline BARI Mung-1 & $1.34 \mathrm{c}$ & $2.79 \mathrm{abcd}$ & $1.05 \mathrm{~cd}$ & $1.73 \mathrm{c}$ \\
\hline BARI Mung-2 & $1.29 \mathrm{c}$ & 2.46 cde & $1.29 \mathrm{~cd}$ & $1.68 \mathrm{~cd}$ \\
\hline BARI Mung-3 & $1.05 \mathrm{c}$ & $1.86 \mathrm{de}$ & $0.71 \mathrm{~d}$ & $1.21 \mathrm{~d}$ \\
\hline BARI Mung-4 & $1.17 \mathrm{c}$ & $3.14 \mathrm{abc}$ & $1.35 \mathrm{bcd}$ & $1.89 \mathrm{bc}$ \\
\hline BARI Mung-5 & $2.11 \mathrm{ab}$ & $3.39 \mathrm{abc}$ & $1.35 \mathrm{bcd}$ & $2.28 \mathrm{ab}$ \\
\hline BARI Mung-6 & $2.39 \mathrm{a}$ & $3.75 \mathrm{a}$ & $2.11 \mathrm{a}$ & $2.75 \mathrm{a}$ \\
\hline BINA Moog-4 & $0.88 \mathrm{c}$ & $1.56 \mathrm{e}$ & $0.71 \mathrm{~d}$ & $1.18 \mathrm{~d}$ \\
\hline BINA Moog-5 & $1.27 \mathrm{c}$ & $3.12 \mathrm{abc}$ & $1.05 \mathrm{~cd}$ & $1.81 \mathrm{bc}$ \\
\hline BINA Moog-6 & $1.17 \mathrm{c}$ & 2.57 abcde & $1.17 \mathrm{~cd}$ & $1.64 \mathrm{~cd}$ \\
\hline BINA Moog-7 & $1.57 \mathrm{bc}$ & $3.69 \mathrm{ab}$ & $1.95 \mathrm{ab}$ & $2.40 \mathrm{a}$ \\
\hline BINA Moog-8 & $1.10 \mathrm{c}$ & 2.59 abcde & $1.05 \mathrm{~cd}$ & $1.58 \mathrm{~cd}$ \\
\hline BU Mug-1 & $1.29 \mathrm{c}$ & $3.14 \mathrm{abc}$ & $1.05 \mathrm{~cd}$ & $1.83 \mathrm{bc}$ \\
\hline BU Mug-2 & $1.27 \mathrm{c}$ & $2.52 \mathrm{bcde}$ & $1.44 \mathrm{bc}$ & $1.74 \mathrm{c}$ \\
\hline BU Mug-4 & $1.17 \mathrm{c}$ & 2.63 abcde & $1.05 \mathrm{~cd}$ & $1.62 \mathrm{~cd}$ \\
\hline Patuakhali local Mung & $1.35 \mathrm{c}$ & $3.02 \mathrm{abcd}$ & $0.88 \mathrm{~cd}$ & $1.75 \mathrm{c}$ \\
\hline $\mathrm{CV}(\%)$ & 33.64 & 25.41 & 32.07 & 17.10 \\
\hline $\mathrm{CD}(0.05)$ & 0.76 & 1.20 & 0.66 & 0.51 \\
\hline
\end{tabular}

Means having dissimilar letter(s) differ significantly at 0.05 level of probability, CD- Critical Difference

\section{CONCLUSION}

Result of the present findings lead towards a conclusion that among fifteen tested varieties none showed to be completely resistant against major insect pests (leaf folder, flea beetle, thrips, gram pod borer and legume pod borer). Rather, higher yields are obtained by cultivating these tested varieties through proper management 
against insect pests in the southern districts of Bangladesh which can play an important role in enhanced domestic production.

\section{REFERENCES}

Bakr, M.A. (1998). Diseases and insect management of mungbean and blackgram. Resource manualLocation-specific technologies for rice-based cropping systems under irrigated conditions. Thana Cereal Technology Transfer and Identification Project, Dhaka. Pp. 201-205.

Bakr, M.A., Afzal, M.A., Hamid, A., Haque, M.M. and Aktar, M.S. (2004). Blackgram in Bangladesh. Lentil Blackgram and Mungbean Development Pilot Project, Publication No.25, Pulses Research Centre, BARI, Gazipur. Pp. 60.

BANGLAPEDIA. (2015). Patuakhali Sadar Upazila. http://en.banglapedia.org. (accessed on $5^{\text {th }}$ February, 2021).

BARI. (2011). Krishi Projukti Hatboi (Handbook on Agro-technology), $5^{\text {th }}$ edition Bangladesh Agricultural Research Institute, Gazipur-1701, Bangladesh. Pp. 164-165.

Chhabra, K.S. and Kooner, B.S. (1985). Problem of flower shedding caused by thrips, Megalurothrips distalis (Karny), on summer mungbean, Vigna radiata (L) Wilczek, and its control. Tropical Pest Management, 31(3): 186-188.

Iftekhar, S. and Islam, M.R. (2004). Managing mangroves in Bangladesh: astrategy analysis. Journal of Coastal Conservation, 10(1): 139-146.

Islam, K.N., Islam, M.M. and Khan, M.M.H. (2021). Weather parameters affecting the population dynamics of leaf folder and pod borers on mungbean, Acta Scientifica Malaysia, 5(1): 36-40.

Islam, K.N., Khan, M.M.H., Islam, M.M., Uddin, M.M. and Latif, M.A. (2021). Prevalence on the infestationof flea beetle (Phyllotreta nigripes) against different varieties of mungbean, Acta Scientifica Malaysia, 5(2): 56-61.

Karim, M.A. and Rahman, M.M. (1991). Status of insect and vertebrate pest management research on pulses. Proceedings of the Second National Workshop on Advances inPulses Research in Bangladesh, 6-8 June 1989, Joydebpur, Bangladesh. Pp. 135-138.

Khattak, M.K., Ali, S. and Chishti, J.I. (2004). Varietal resistance of mungbean (Vigna radiata L.) against whitefly (Bemisia tabaci genn.), jassid (Amrasca devastans dist.), and thrips (Thrips tabaci lind.). Pakistan Journal of Entomology, 26(1): 9-12.

Lal, S.S. (1985). A review of insect pests of mungbean and their control in India. Tropical Pest Management, 31(2): 105-114.

Mondol, M.E.A., Rahman, H., Rashid, M.H., Hossain, M.A. and Islam, M.M. (2013). Screening of mungbean germplasm for resistance to mungbean yellow mosaic virus. International Journal of Sustainable Crop Production, 8(1): 11-15.

Nadeem, S., Hamed, M., Asghar, M.J., Abbas, G. and Saeed, N.A. (2014). Screening of mungbean (Vigna radiata L. Wilczek) genotypes against sucking insect pests under natural field conditions. Pakistan Journal of Zoology, 46(3): 863-866.

Patnaik, N.P., Samalo, A.P. and Samalo, B.N. (1986). Susceptibility of some early varieties of pigeon pea for pod borer under protected conditions. Legume Research-An International Journal, 9(1): 7-10. 
Sandhya Rani, C., Ramachandra Rao, G., Chalam, M.S.V., Anil Kumar, P. and Srinivasa Rao, V. (2014). Field Screening of Greengram Genotypes against Maruca vitrata in Summer. Journal of Agriculture and Crop Science, 1: 18-25.

Sehgal, V.K. and Ujagir, R. (1988). Insect and pest management of mungbean in India. Mungbean. Proceedings of the Second International Symposium. Asian Vegetable Research and Development Centre, Shanhua, Taiwan.

Shafique, M., Nadeem, S., Hamed, M., Atta, B.M. and Shah, T.M. (2009). Performance of some advance desi chickpea genotypes against pod borer, Helicoverpa armigera (Hubner) resistance. Pakistan Journal of Zoology, 41(4): 277-280.

Yadav, D.S., Panwar, K.S. and Singh, V.K. (1994). Management of pulse crops in sequential cropping. In: Abstract. Proceedings Intecropping Symposium on Pulses Research. 2-6 April, 1994, New Delhi, India. Pp. 27. 